NASA/CR-2001-211270

ICASE Report No. 2001-41

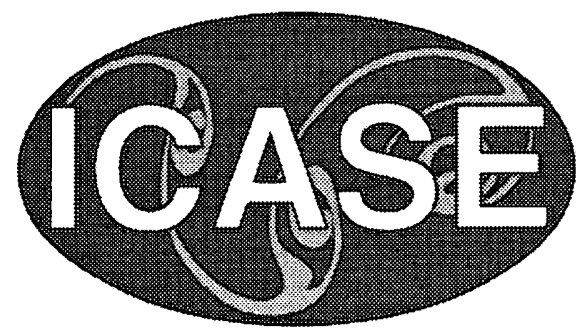

\title{
Liquid Crystals Derived from 2-phenyl-isoindoles. Synthesis and Characterization
}

Kenny G. Jow

Massachusetts Institute of Technology, Cambridge, Massachusetts

Theo J. Dingemans

ICASE, Hampton, Virginia 


\section{The NASA STI Program Office ... in Profile}

Since its founding, NASA has been dedicated to the advancement of aeronautics and space science. The NASA Scientific and Technical Information (STI) Program Office plays a key part in helping NASA maintain this important role.

The NASA STI Program Office is operated by Langley Research Center, the lead center for NASA's scientific and technical information. The NASA STI Program Office provides access to the NASA STI Database, the largest collection of aeronautical and space science STI in the world. The Program Office is also NASA's institutional mechanism for disseminating the results of its research and development activities. These results are published by NASA in the NASA STI Report Series, which includes the following report types:

- TECHNICAL PUBLICATION. Reports of completed research or a major significant phase of research that present the results of NASA programs and include extensive data or theoretical analysis. Includes compilations of significant scientific and technical data and information deemed to be of continuing reference value. NASA's counterpart of peer-reviewed formal professional papers, but having less stringent limitations on manuscript length and extent of graphic presentations.

\section{- TECHNICAL MEMORANDUM.}

Scientific and technical findings that are preliminary or of specialized interest, e.g., quick release reports, working papers, and bibliographies that contain minimal annotation. Does not contain extensive analysis.

- CONTRACTOR REPORT. Scientific and technical findings by NASA-sponsored contractors and grantees.
- CONFERENCE PUBLICATIONS. Collected papers from scientific and technical conferences, symposia, seminars, or other meetings sponsored or cosponsored by NASA.

- SPECIAL PUBLICATION. Scientific, technical, or historical information from NASA programs, projects, and missions, often concerned with subjects having substantial public interest.

- TECHNICAL TRANSLATION. Englishlanguage translations of foreign scientific and technical material pertinent to NASA's mission.

Specialized services that complement the STI Program Office's diverse offerings include creating custom thesauri, building customized data bases, organizing and publishing research results ... even providing videos.

For more information about the NASA STI Program Office, see the following:

- Access the NASA STI Program Home Page at http://www.sti.nasa.gov

- Email your question via the Internet to help@sti.nasa.gov

- Fax your question to the NASA STI Help Desk at (301) 621-0134

- Telephone the NASA STI Help Desk at (301) 621-0390

- Write to: NASA STI Help Desk NASA Center for AeroSpace Information 7121 Standard Drive Hanover, MD 21076-1320 
NASA/CR-2001-211270

ICASE Report No. 2001-41

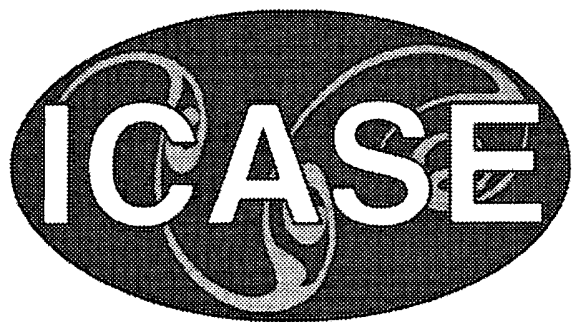

\section{Liquid Crystals Derived from 2-phenyl-isoindoles. Synthesis and Characterization}

Kenny G. Jow

Massachusetts Institute of Technology, Cambridge, Massachusetts

Theo J. Dingemans

ICASE, Hampton, Virginia

ICASE

NASA Langley Research Center

Hampton, Virginia

Operated by Universities Space Research Association

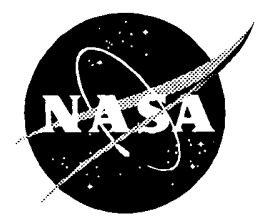

National Aeronautics and

Space Administration

December 2001 
Available from the following:

NASA Center for AeroSpace Information (CASI)

7121 Standard Drive

Hanover, MD 21076-1320

(301) 621-0390
National Technical Information Service (NTIS)

5285 Port Royal Road

Springfield, VA 22161-2171

(703) $487-4650$ 


\title{
LIQUID CRYSTALS DERIVED FROM 2-PHENYL-ISOINDOLES. SYNTHESIS AND CHARACTERIZATION
}

\author{
K.G. JOW $\ddagger$ AND T.J. DINGEMANS*
}

\begin{abstract}
Phenyl-isoindole was investigated as the rigid core unit in a series of asymmetric mesogenic molecules. When the 2-phenyl-isoindole core was terminated with a hexyl tail, no mesophase formation could be observed. When 4-n-(tridecafluorohexyl) was used, however, we observed both monotropic and enantiotropic phase behavior. We found that most functionalities at the anhydride 5-position results in the formation of smectic $\mathrm{A}(\mathrm{SmA})$ phases in the temperature range of $70-180^{\circ} \mathrm{C}$. Functionalities at the anhydride 4-position suppress mesophase formation. Large substituents $\left(-\mathrm{Br},-\mathrm{NO}_{2}\right)$ and symmetric substitution patterns (5,6-dichloro, 4,7-dichloro and 4,5,6,7-tetrachloro) on the anhydride moiety increase the melting point and destabilize the mesophase. Temperature dependent X-ray diffraction experiments suggest an interdigitated $\mathrm{SmA}$ packing for this family of compounds.
\end{abstract}

Key words. liquid crystals, smectic A, 2-phenyl-isoindole, fluorinated imides, self-adaptive optics and filters

Subject classification. Structures and Materials

1. Introduction. Fluorinated polyimides are well known for their mechanical properties, thermal stability, and ability to survive in aggressive environments [1]. Currently, very few examples exist in which imides are used as mesogenic building blocks in low-molar-mass thermotropic liquid crystals (LCs) of the core-tail type. Eiselt and co-workers [2] reported a series of LC di-imides based on 3,3,4,4-biphenyltetracarboxylic dianhydride (BPDA) as the central mesogenic core. They concluded that the dianhydride core adopts the trans configuration when reacted with 4-n-alkylanilines or 4-n-alkoxyanilines, and they exclusively observed the $\mathrm{SmA}$ phase in the temperature range of $226-293{ }^{\circ} \mathrm{C}$. Bialecka-Florjanczyk and Orzeszko [3] reported the synthesis of a series of monothio- and dithiotrimellitimides. Nematic and smectic phases were observed in 4-cyano substituted compounds, whereas only a nematic phase was observed in the 4-decyloxy analog. Transition temperatures for these compounds were reported to be in the range of $49-203{ }^{\circ} \mathrm{C}$. Most recently Berdagué et al. [4] showed that 2-phenyl-indazole can be used as a mesogenic building block for LCs and reported the existence of both nematic and smectic mesophases.

Herein, we present the synthesis and characterization of new imide-based LCs prepared from simple anhydrides and 4-n-(tridecafluorohexyl)aniline. This class of heterocyclic compounds are better known as 2-phenyl-isoindole-1,3-diones and have an asymmetric calamitic rigid core structure (shown below) that is conducive to mesophase formation.

*Author for corespondence. ICASE, Mail Stop 132C, NASA Langley Research Center, Hampton, VA 23681-2199 (email: t.j.dingemans(larc.nasa.gov). This research was supported by the National Aeronautics and Space Administration under Contract No. NAS1-97046 while the author was in residence at ICASE, Structures and Materials, NASA Langley Research Center, Hampton, VA 23681-2199.

$\ddagger$ Department of Materials Science and Engineering, Massachusetts Institute of Technology, 77 Massachusetts Avenue, Cambridge, MA 02139-4307 


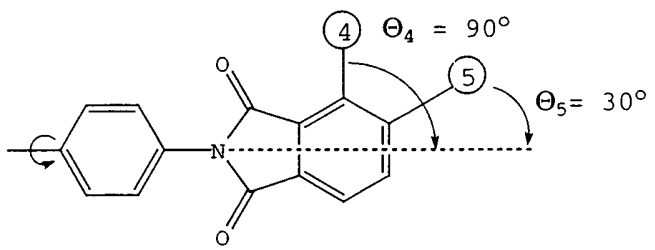

Potential substituents on the anhydride have to be considered as lateral substituents because no para position is available and, depending on the position, they are placed at a $90^{\circ}$ angle (4-position) or at a $30^{\circ}$ angle (5-position) with respect to the molecular long axis. our main interests were to examine the effects of the anhydride substituents on mesophase type and mesophase stability in a series of 2-phenyl-isoindoles based model compounds.

In the first series we have modified 2-(4- $n$-tridecafluorohexyl-phenyl)-isoindole-1,3-dione (1) by introducing simple substituents $\left(\mathrm{X}=\mathrm{H}, \mathrm{Me}, \mathrm{OMe}\right.$, and $\left.\mathrm{NO}_{2}\right)$ at the anhydride 5-position (I). Most anhydrides were commercially available or could be made in one or two steps.

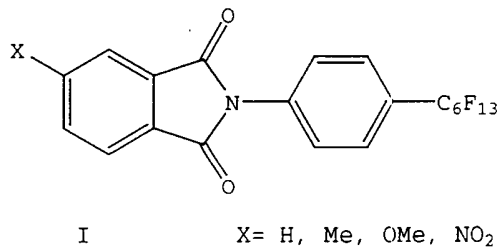

Next we considered 2-(4- $n$-tridecafluorohexyl-phenyl)-isoindole-1,3-dione (1) with different halogen substituents $(\mathrm{X}=\mathrm{F}, \mathrm{Cl}, \mathrm{Br})$ and we studied the phase behavior when the halogens were moved from the anhydride's 5-position to the 4-position (II). By doing so, we have reduced the mesogen effective length (i.e., lowered the symmetry) and in addition placed the electrostatic dipole moment at a $90^{\circ}$ angle with respect to the molecular long axis.

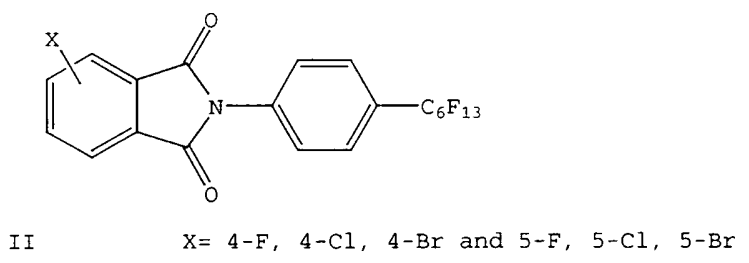

Finally, in the last series (III) we explored the effects of multiple halogen $(\mathrm{X}=\mathrm{Cl})$ on the terminal anhydride moiety of 2-(4- $n$-tridecafluorohexyl-phenyl)-isoindole-1,3-dione (1). The mono-substituted analogs, with chlorine in the 4- or 5-position, are asymmetric, whereas the di- and tetra-substituted analogs are symmetric.

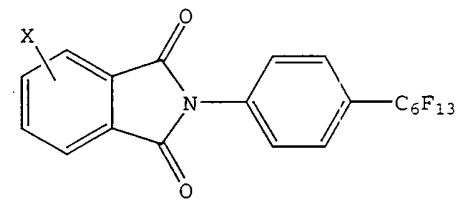


2. Results and Discussion. Three series of 2-phenyl-isoindole-based thermotropic liquid crystals were successfully synthesized in high yields, using a simple one-step procedure. The structures of all compounds were confirmed by proton, carbon, and fluorine nuclear magnetic resonance $\left({ }^{1} \mathrm{H}\right.$-NMR, $\left.{ }^{13} \mathrm{C}-\mathrm{NMR},{ }^{19} \mathrm{~F}-\mathrm{NMR}\right)$ and infrared spectroscopy (FTIR). Although we initially included 4-hexylaniline in our studies, we could not detect liquid crystalline behavior in any of these systems. This observation suggests that the 2-phenylisoindole core by itself exhibits poor mesogenic properties. We were more successful when we switched from 4-hexylaniline to 4-n-(tridecafluorohexyl)aniline as the terminal tail segment. As Bunn and Houwens [5] showed, the larger fluorine atoms force a helicoidal chain conformation, and this results in a stiffer chain than its hydrocarbon analogue. In addition, the fluorinated tail is chemically incompatible with the aromatic 2-phenyl-isoindole core, which leads to microphase separation and consequently promotes the formation of smectics $[6-8]$.

2.1. Mesomorphic Properties. The phase behavior and DSC results of the first series of 5-substituted 2-(4-n-tridecafluorohexyl-phenyl)-isoindole-1,3-diones are presented in Table 1.

TABLE 1

Phase transition temperatures $\left({ }^{\circ} \mathrm{C}\right.$ ) and enthalpy's (italic) for the 5-substituted 2 -(4-n-tridecafluorohexyl-phenyl)-isoindole-1,3-diones

\begin{tabular}{|c|c|c|c|c|c|}
\hline No. & $(\mathrm{X}=)$ & $\mathbf{K}$ & $\mathbf{K}^{\prime}$ & $\mathrm{S}_{A}$ & I \\
\hline \multirow[b]{2}{*}{ (1) } & \multirow[b]{2}{*}{$-\mathbf{H}$} & - $140.1(35.1)$ & & & $\bullet$ \\
\hline & & - $103.5(-27.0)$ & & - $131.6(-4.0)$ & $\bullet$ \\
\hline \multirow{2}{*}{$(2)$} & \multirow{2}{*}{$-\mathrm{Me}$} & - $145.1(50.6)$ & & - $165.2(9.2)$ & $\bullet$ \\
\hline & & - $102.0(-44.8)$ & & - $164.7(-9.2)$ & $\bullet$ \\
\hline \multirow{2}{*}{ (3) } & \multirow{2}{*}{-OMe } & - $133.8(5.5)$ & - $149.9(34.9)$ & - $181.5(6.1)$ & $\bullet$ \\
\hline & & - $100.2(-8.6)$ & - $109.2(-21.0)$ & - $180.6(-6.2)$ & $\bullet$ \\
\hline \multirow{2}{*}{ (4) } & \multirow{2}{*}{$-\mathrm{NO}_{2}$} & - $147.5(3.4)$ & - $179.2(42.6)$ & & $\bullet$ \\
\hline & & - $155.0(-40.5)$ & & & $\bullet$ \\
\hline
\end{tabular}

From these results it becomes evident that the parent compound 2-(4-n-tridecafluorohexyl-phenyl)isoindole-1,3-dione (1) is a poor mesogen. This compound shows a monotropic SmA phase upon cooling only. When lateral substituents are introduced at the anhydride 5-position, $\mathrm{X}=-\mathrm{Me}(\mathbf{2})$ and $-\mathrm{OMe}(\mathbf{3})$, an enantiotropic $\operatorname{SmA}$ phase is observed that is stable over a wide temperature range. Figure 1 shows a DSC heating and cooling scan of 5-methoxy-2-(4-n-tridecafluorohexyl-phenyl) -isoindole-1,3-dione (3). Upon cooling this compound shows a $\mathrm{SmA}$ phase from $150-182^{\circ} \mathrm{C}$, but upon cooling, the $\mathrm{SmA}$ range extends over $70^{\circ} \mathrm{C}\left(109-181^{\circ} \mathrm{C}\right)$. This super cooling behavior is typically observed for all mesogenic 2-phenyl-isoindoles used in this study. 


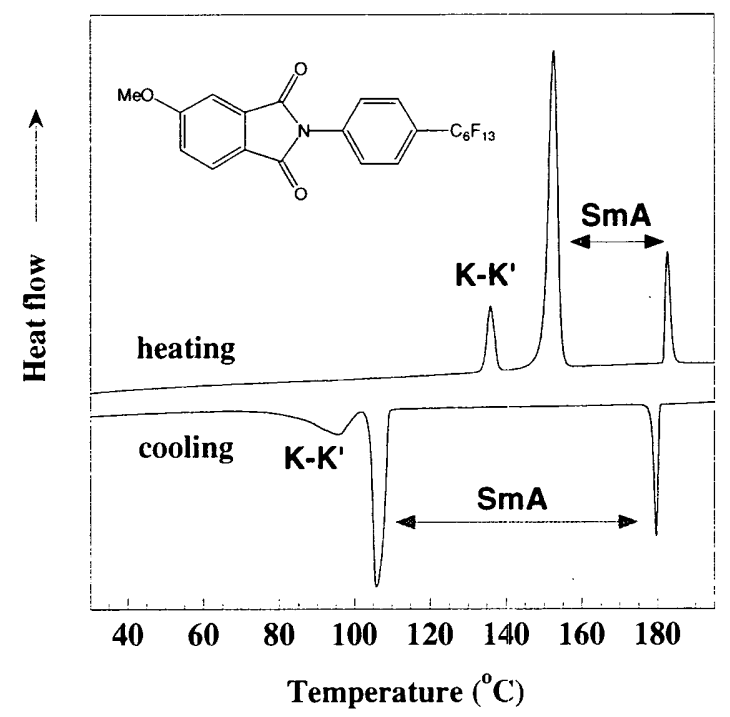

FIG. 1. Second heating and cooling trace of 5-methoxy-2-(4-n-tridecafluorohexyl-phenyl)-isoindole-1,3-dione

When a nitro group $\left(\mathrm{X}=-\mathrm{NO}_{2}\right)(4)$ is introduced, no mesomorphic behavior could be observed. This is quite surprising, because the nitro functionality is a highly polarizable group and is often found to promote mesophase formation [9]. In this case, however, we believe that the large planar nitro group promotes crystallization, which results in a high melting temperature obscuring the underlying LC phase. The phase behavior of the 5-substituted 2-(4-n-tridecafluorohexyl-phenyl)-isoindole -1,3-diones is summarized in Figure 2 , wherein the compounds are arbitrarily plotted on the $\mathrm{X}$-axis.

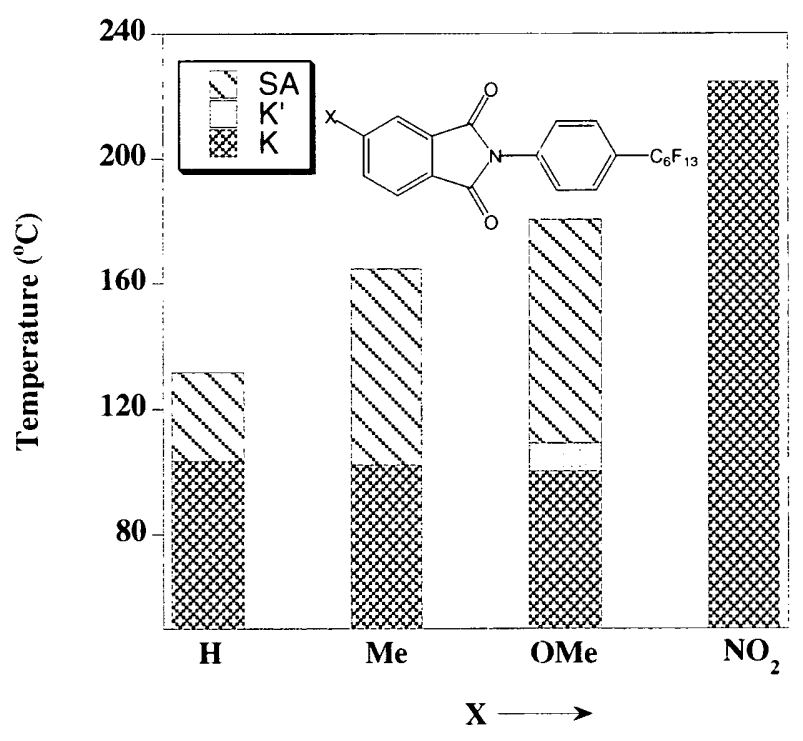

FIG. 2. Mesophase ranges for the 5-substituted 2-(4-n-tridecafluorohexyl-phenyl)-isoindole-1,3-diones

The DSC results for the halogen modified 2-(4-n-tridecafluorohexyl-phenyl)-isoindole -1,3-diones are summarized in Table 2 . 
TABLE 2

Phase transition temperatures $\left({ }^{\circ} \mathrm{C}\right.$ ) and enthalpy's (italic) for the mono-halogenated 20-(4-n-tridecafluorohexyl-phenyl)-isoindole-1,3-diones

\begin{tabular}{|c|c|c|c|c|c|}
\hline No. & $(X=)$ & $\mathbf{K}$ & $\mathrm{K}^{\prime}$ & $\mathrm{S}_{A}$ & I \\
\hline \multirow[b]{2}{*}{ (5) } & \multirow[b]{2}{*}{$4-F$} & - $158.1(40.4)$ & & & • \\
\hline & & - $127.5(-26.2)$ & & & - \\
\hline \multirow{2}{*}{$(6)$} & \multirow{2}{*}{$5-F$} & - $126.4(26.9)$ & & - $137.5(4.9)$ & - \\
\hline & & - $101.8(-25.0)$ & & - $136.5(-4.9)$ & $\bullet$ \\
\hline \multirow{2}{*}{ (7) } & \multirow{2}{*}{ 4-Cl } & - $111.0(26.6)$ & & & $\bullet$ \\
\hline & & - $69.8(-16.4)$ & & - $85.3(-1.6)$ & $\bullet$ \\
\hline \multirow{2}{*}{ (8) } & \multirow{2}{*}{ 5-Cl } & - $143.9(3.2)$ & - $155.2(25.4)$ & - $164.8(6.5)$ & $\bullet$ \\
\hline & & - $128.7(-22.2)$ & & - $163.6(-6.7)$ & - \\
\hline \multirow{2}{*}{ (9) } & \multirow{2}{*}{$4-\mathrm{Br}$} & - $116.4(32.2)$ & & & $\bullet$ \\
\hline & & - $82.9(-17.5)$ & & & $\bullet$ \\
\hline \multirow{2}{*}{ (10) } & \multirow{2}{*}{$5-\mathrm{Br}$} & - $174.0(38.8)$ & & & - \\
\hline & & - $141.6(-30.1)$ & & - $164.7(-6.2)$ & $\bullet$ \\
\hline
\end{tabular}

Introducing halogens at the anhydride's 5-position, initially results in an increase in melt transition and stabilization of the $\mathrm{SmA}$ phase as a function of increased halogen size for $\mathrm{X}=-\mathrm{F}(6)$ and $-\mathrm{Cl}(8)$. When $\mathrm{X}=$ - $\mathrm{Br}(\mathbf{1 0})$, however, the stability of the $\mathrm{SmA}$ phase is slightly reduced, which is probably because the dipole moment decreases with increasing halogen size and the tendency to crystallize.

When the halogens ( $\mathrm{X}=-\mathrm{F},-\mathrm{Cl}$ and $-\mathrm{Br}$ ) are moved from the anhydride's 5-position to the 4-position, we observe a dramatic reduction of melting temperature for all three compounds. In addition, it is interesting to see that with the exception of the 4-Cl (7) isomer the SmA phase is completely suppressed in the 4-F (5) and 4-Br (9) isomers. Intuitively, one would expect to see little or no change in phase behavior between the 4-F and 5-F isomers because moving the small fluorine atom from the 5- to the 4-position does not significantly affect the overall molecular shape. Translating the bulky chlorine and bromine atoms from the 5- to the 4-position, however, reduces the overall molecular symmetry and results in a considerable drop in melt transition. At this moment we are unable to explain why only the $4-\mathrm{Cl}$ isomer (7) exhibits a LC: phase. The phase behavior of the halogen modified 2-(4- $n$-tridecafluorohexyl-phenyl)-isoindole-1,3-diones is summarized in Figure 3. 


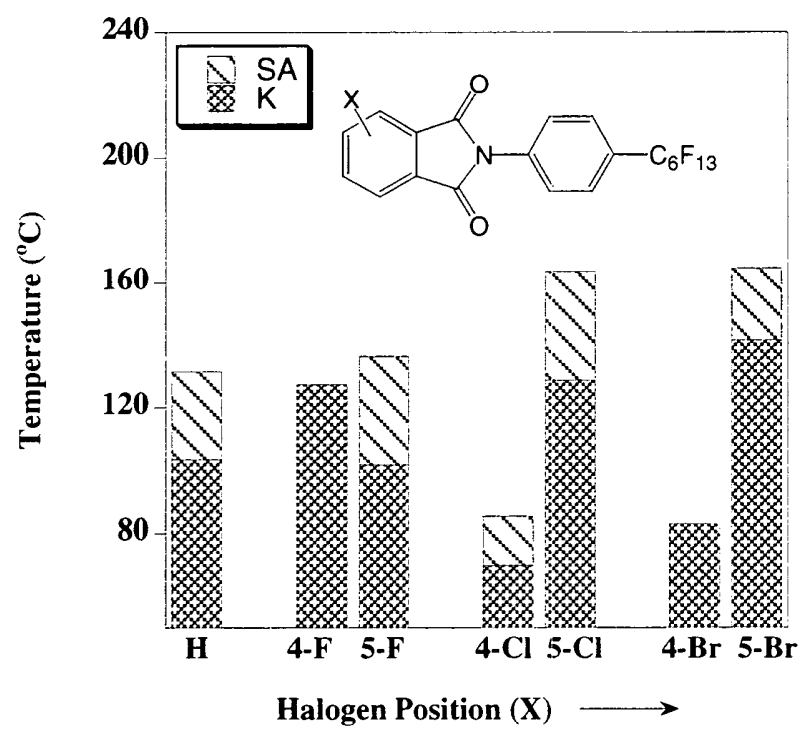

FIG. 3. Mesophase ranges for the mono-halogenated 2-(4-n-tridecafluorohexyl-phenyl)-isoindole-1,3-diones

We also investigated the effects of multi-halogenation on the phase behavior of 2-(4- $n$-tridecafluorohexylphenyl)-isoindole-1,3-dione model compounds. The DSC results are shown in Table 3.

TABLE 3

Phase transition temperatures $\left({ }^{\circ} \mathrm{C}\right)$ and enthalpy's (italic) for the multi chlorinated 2-(4-n-tridecafluorohexyl-phenyl)-isoindole-1,3-diones

\begin{tabular}{|c|c|c|c|c|c|}
\hline No. & $(\mathrm{X}=)$ & $\mathbf{K}$ & $\mathbf{K}^{\prime}$ & $\mathbf{S}_{A}$ & I \\
\hline \multirow[b]{2}{*}{ (11) } & \multirow[b]{2}{*}{$5,6-\mathrm{Cl}$} & - $186.4(40.7)$ & & & $\bullet$ \\
\hline & & - $167.3(-34.0)$ & & - 169.0* & - \\
\hline \multirow{2}{*}{ (12) } & \multirow{2}{*}{$4,7-\mathrm{Cl}$} & - $140.0(18.4)$ & - $144.2(19.9)$ & & $\bullet$ \\
\hline & & - $102.2(-30.3)$ & & & $\bullet$ \\
\hline \multirow{2}{*}{ (13) } & \multirow{2}{*}{$4,5,6,7-\mathrm{Cl}$} & - $239.6(45.1)$ & & & $\bullet$ \\
\hline & & - $220.2(-42.6)$ & & & $\bullet$ \\
\hline
\end{tabular}

* Observed by optical microscopy only

Introducing more than one chlorine atom results in a dramatic loss of mesophase stability. Figure 4 shows the phase behavior of all chlorine $(\mathrm{X}=-\mathrm{Cl})$ modified mesogens. We were surprised to see that the isotropization temperatures of the $5-\mathrm{Cl}(\mathbf{8})$ and 5,6-Cl (11) mesogens are very similar. Placing two chlorine atoms at the anhydride 5- and 6- position increases the strength of the molecular dipole in the direction of the molecular long axis, which would promote mesophase stabilty. In this case, however, the two chlorine atoms also increase the overall molecular symmetry and this promotes crystallization, which is confirmed by the higher melting point of this compound. The result is a small monotropic SmA phase that could be observed upon cooling only. When the chlorine atoms are placed at the anhydride 4- and 7 -position (12) the same trend is observed as for the 4- $\mathrm{Cl}(7)$ compound. In the 4,7- $\mathrm{Cl}$ compound we did not find any mesophases, but again a significant decrease in melting point was observed. It is obvious that placing 
substituents on the 4- and 7-position results in a reduction of the aspect ratio of the molecule and therefore a reduction in mesophase stability is observed. Perchlorination of the anhydride moiety as in the case of the 4,5,6,7-Cl compound (13) leads to a highly symmetric compound with a very high melting point exhibiting no mesophase. Again, the high symmetry of this compound seems to favor crystallization above mesophase formation.

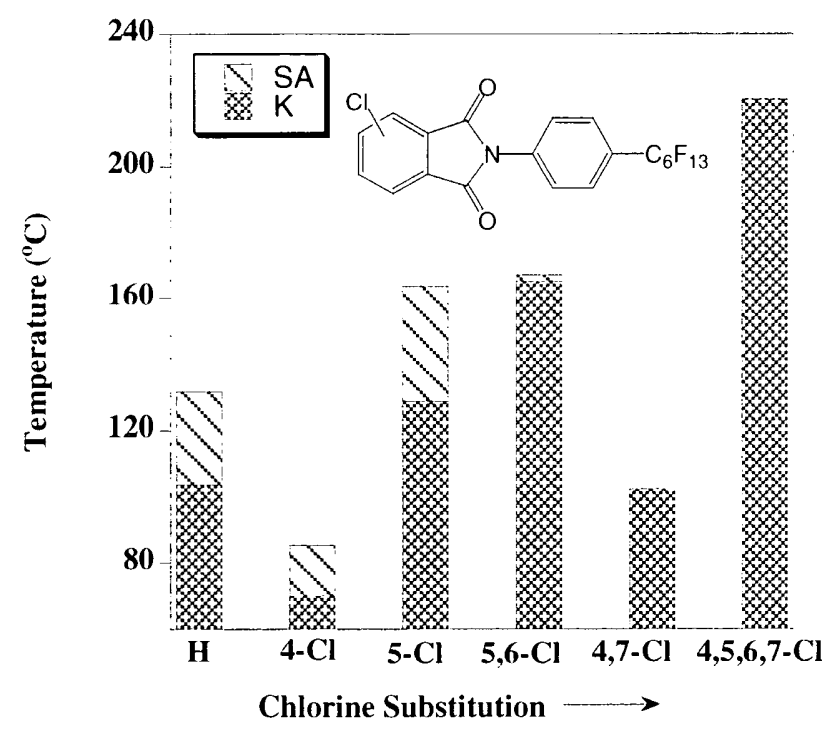

FIG. 4. Mesophase ranges for the mono-, di- and tetra-chlorinated 2-(4-n-tridecafluorohexyl-phenyl)isoindole-1,3-diones

2.2. Optical Microscopy Results. All reported mesogenic compounds exhibit a classical focal conic texture, which is indicative of the smectic A phase $(\operatorname{SmA})$. Figure 5 shows the texture of 5-methoxy-2-(4-ntridecafluorohexyl-phenyl)-isoindole-1,3-dione (3) in the $\mathrm{Sm} A$ phase at $160{ }^{\circ} \mathrm{C}$.

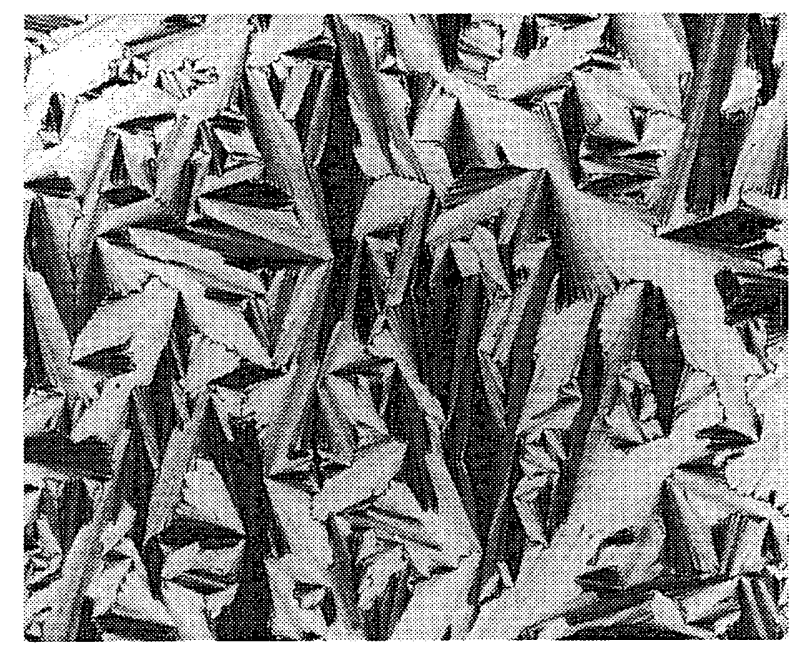

FIG. 5. Smectic A (SmA) focal conic texture of 5-methoxy-2-(4-ntridecafluorohexyl-phenyl)-isoindole-1,3-dione at $154^{\circ} \mathrm{C}$; crossed polars and $20 \mathrm{X}$.

2.3. X-Ray Diffraction Results. Figure 6 shows the X-ray diffractogram of 5-methoxy-2-(4-n-trideca fluorohexyl-phenyl)-isoindole-1,3-dione (3) in the unaligned $\mathrm{SmA}$ phase at $160^{\circ} \mathrm{C}$. Attempts to orient the 
samples in the SmA phase using a strong magnetic field were unsuccessful. This diffraction pattern is representative for all mesogens and appears to be temperature independent.

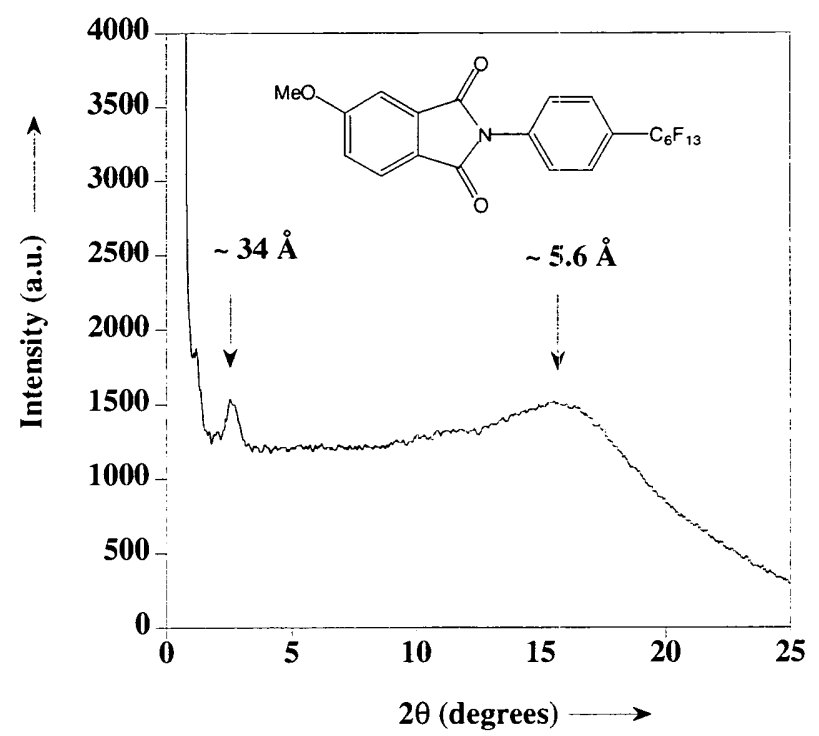

FIG. 6. X-ray diffractogram of 5-methoxy-2-(4-n-tridecafluorohexyl-phenyl)-isoindole-1,3-dione in the smectic A (SmA) phase at $154^{\circ} \mathrm{C}$.

The broad peak at the wide-angle region $\left(2 \theta \sim 16^{\circ}\right)$ is indicative of liquid-like in-plane order of the mesogens within the layers, which is typically observed for lower order smectics phases. The small angle reflection $\left(2 \theta \sim 2.5^{\circ}\right)$ corresponds to a layer spacing (d) of $\sim 34 \AA$. The molecular length (l) of this mesogen in its most extended conformation is $18.1 \AA$ as estimated by Spartan, and is confirmed by the (001) and (002) reflections in the crystalline phase. Based on these results we believe that our data suggest a bilayer SmA packing model with interdigitating fluorinated tails as presented in Figure 7.

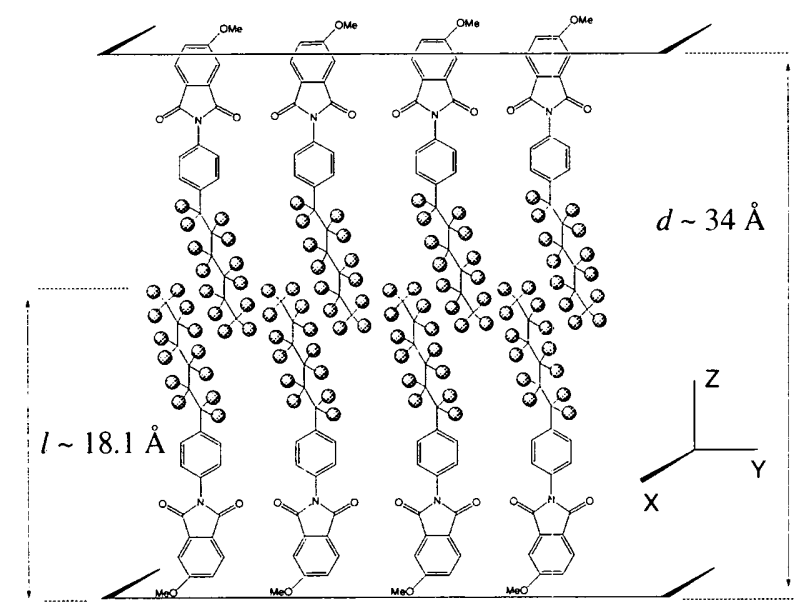

FIG. 7. Proposed bilayer packing of 5-methoxy-2-(4-n -tridecafluorohexyl-phenyl)-isoindole-1,3-dione in the smectic A (SmA) phase with interdigitating fluorinated tails.

3. Conclusion. For certain space applications a need exists for low-molecular weight thermotropic liquid crystalline materials that can be used in self-adaptive optics and filters. Potential candidates need to withstand the extreme temperature fluctuations, presence of atomic oxygen, and high-energy radiation 
conditions that exist in low earth orbit (LEO). Most thermotropic liquid crystals rely on alkyl type flexible tails, but in our applications alkyl groups do not have the required long-term stability. We are, therefore, exploring the possibility of using low-molecular weight imides with perfluorinated tails. We have synthesized and compared several series of 2-(4-n-tridecafluorohexyl-phenyl)-isoindole-1,3-dione liquid crystals. We found that 2-(4-n-tridecafluorohexyl-phenyl)-isoindole -1,3-dione based liquid crystals are able to form stable $\mathrm{SmA}$ phases with accessible temperature ranges $\left(70-180^{\circ} \mathrm{C}\right)$. Although many different functionalities are tolerated at the anhydride's 5-position, substituents at the anhydride 4-position and multiple halogen substitution destabilize the $\mathrm{SmA}$ phase. X-ray diffraction experiments suggest an interdigitated bilayer SmA packing for this family of compounds.

\section{Experimental.}

4.1. Instrumentation. The structures of the final products were confirmed using ${ }^{1} \mathrm{H}-\mathrm{NMR},{ }^{13} \mathrm{C}-\mathrm{N} M R$, and ${ }^{19} \mathrm{~F}$-NMR spectroscopy. The spectra were recorded using a Bruker Avance 300 spectrometer (300 MHz), and the infrared spectra were collected using a Nicolet Magna-IR. Spectrometer 750.

Transition temperatures were determined using a Perkin Elmer Pyris differential scanning calorimeter, calibrated with indium $(99.99 \%)\left(\mathrm{mp} 156.6^{\circ} \mathrm{C}, \Delta \mathrm{H}=28.315 \mathrm{~J} / \mathrm{g}\right)$ and $\operatorname{tin}(99.99 \%)\left(\mathrm{mp} 232.0^{\circ} \mathrm{C}, \Delta \mathrm{H}=54.824\right.$ $\mathrm{J} / \mathrm{g}$ ). Heating and cooling scans were recorded at $10^{\circ} \mathrm{C} / \mathrm{min}$.

Mesophases were identified with an Olympus BH-2 optical microscope, equipped with a Mettler Toledo FP82H hot stage. Samples were examined between glass microscope slides.

Variable temperature X-ray diffraction analysis was carried out with an Enraf Nonius FR 590 system equipped with a two-dimensional image plate detector $(2500 \times 2500)$ pixels, $80 \mu \mathrm{m}$ resolution. Unaligned samples were analyzed using monochromatic $\mathrm{Cu}-\mathrm{K} \alpha(\lambda=1.54 \AA)$ radiation at various temperautures. A Mettler Toledo FP82H hot stage was used to control the temperature.

4.2. Materials. All start materials were obtained from Aldrich, with the exception of 1-iodotridecafluoro hexane, 4-iodoaniline (Fluka), and 4-chlorophthalic anhydride (TCI). Both 3-bromophthalic anhydride and 4-methoxy phthalic anhydride were synthesized according to a procedure reported by Soucy et al. [10], and 4- $n$ - (tridecafluorohexyl)aniline was prepared according to Yoshino et al [11].

All LC model compounds were synthesized as outlined in Scheme 1. The amic acid intermediate was formed in the initial room temperature step, and the temperature was raised to reflux, the amic acid was dehydrated to the corresponding imide. Although the reaction appeared to be finished after 4 hours (TLC $90 / 10$ hexane/ethyl acetate), we refluxed the reaction mixtures overnight for convenience. This procedure is simple, and gives the desired products in high yields. The products often crystallized from the reaction mixture upon cooling, which minimized product work-up. 


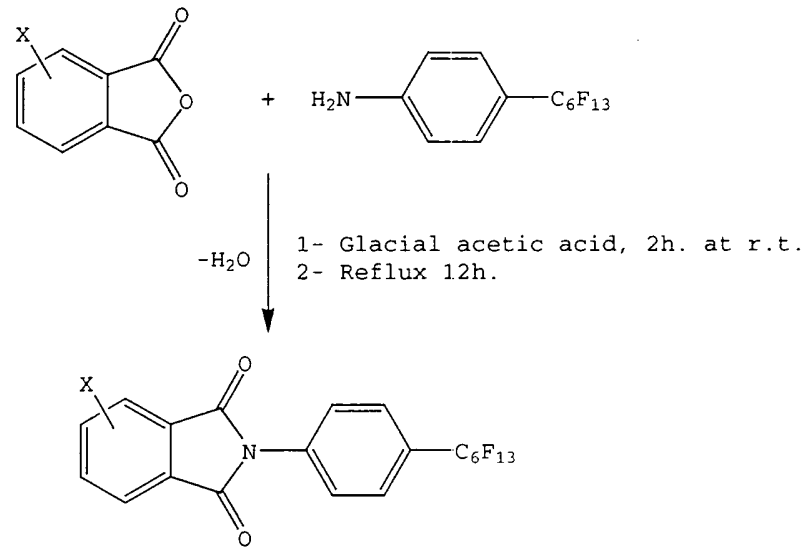

SCHEME 1. Synthesis of the 2-phenyl-isoindole model compounds.

\subsection{Synthesis.}

3-Bromophthalic anhydride A three-neck flask equipped with a magnetic stir bar and reflux condensor was charged with 3 -bromo- $o$-xylene $(3 \mathrm{~g}, 0.016 \mathrm{~mol})$, cetyltrimethylammonium bromide $(0.01 \mathrm{~g}, 0.03 \mathrm{mmol})$ and $60 \mathrm{ml}$ water. Potassium permanganate $(10 \mathrm{~g}, 0.063 \mathrm{~mol})$ was added in three portions and the reaction mixture was stirred at $60^{\circ} \mathrm{C}$ for $24 \mathrm{~h}$. The warm reaction mixture was filtered and the filtrate was acidified with $10 \mathrm{ml} \mathrm{HCl} \mathrm{(37 \% ).} \mathrm{The} \mathrm{volume} \mathrm{was} \mathrm{reduced} \mathrm{to} 50 \%$ and extracted with diethyl ether (3x), and the combined ether layers were dried over $\mathrm{MgSO}_{4}$. The solvent was removed by distillation and an off-white product was collected and refluxed in acetic anhydride for $4 \mathrm{~h}$. Upon cooling, colorless crystals formed. Yield: $1.81 \mathrm{~g}(50 \%)$; mp $135{ }^{\circ} \mathrm{C}\left(\mathrm{mp} 134^{\circ} \mathrm{C}[10]\right)$; FT-IR (KBr) $1772\left(C=O_{\text {anhydride }}\right), 1858\left(C=O_{\text {anhydride }}\right)$ $\mathrm{cm}^{-1}$

4-Methoxyphthalic anhydride Same procedure as described for 3-bromophthalic anhydride. Oxidation was complete after $5 \mathrm{~h}$. Yield: $4 \mathrm{~g}(35 \%)$; mp $95^{\circ} \mathrm{C}\left(\mathrm{mp} 95^{\circ} \mathrm{C}\right.$ [10]); FT-IR (KBr) $1774\left(C=O_{\text {anhydride }}\right)$, $1847\left(C=O_{\text {anhydride }}\right) \mathrm{cm}^{-1}$

4-n-(Tridecafluorohexyl)aniline A $250 \mathrm{ml}$ 2-neck flask equipped with reflux condensor and nitrogen inlet was charged with 1-iodotridecafluorohexane $(67.9 \mathrm{~g}, 0.152 \mathrm{~mol})$, 4-iodoaniline $(30.0 \mathrm{~g}, 0.13 \overline{\mathrm{t}} \mathrm{mol})$, copper bronze $(29.0 \mathrm{~g}, 0.456 \mathrm{~mol})$ and $150 \mathrm{ml}$ DMSO. This suspension was heated at $120{ }^{\circ} \mathrm{C}$ for $12 \mathrm{~h}$. under a nitrogen atmosphere. The reaction mixture was cooled to $50{ }^{\circ} \mathrm{C}$ and the copper iodide and excess copper bronze were removed by vacuum filtration. Water $(100 \mathrm{ml})$ was added to the filtrate and the aqueous layer was extracted $(3 \mathrm{x})$ with diethyl ether. The ether layer was washed with water and dried over $\mathrm{MgSO}_{4}$ and the solvent was removed by distillation. The title compound was purified by vacuum distillation $\left(60{ }^{\circ} \mathrm{C} / 25\right.$ mTorr). Yield: $37.5 \mathrm{~g}(61 \%) .{ }^{1} \mathrm{H}-\mathrm{NMR}\left(\mathrm{CDCl}_{3}\right) \delta(\mathrm{ppm}): 3.85(\mathrm{~s}, 2 \mathrm{H}), 6.57(\mathrm{~d}, 2 \mathrm{H}, J=9 \mathrm{~Hz}), 7.23(\mathrm{~d}, 2 \mathrm{H}$, $J=8 \mathrm{~Hz}) ;{ }^{13} \mathrm{C}-\mathrm{NMR} \delta(\mathrm{ppm}): 114.23,117.77,118.03,128.19,128.27,128.36,149.73 ;{ }^{19} \mathrm{~F}-\mathrm{NMR} \delta(\mathrm{ppm}):-82$ $\left(\omega-\mathrm{CF}_{3}\right),-110\left(\epsilon-\mathrm{CF}_{2}\right),-122\left(\delta-\mathrm{CF}_{2}\right),-123\left(\gamma-\mathrm{CF}_{2}\right),-125\left(\beta-\mathrm{CF}_{2}\right),-127\left(\alpha-\mathrm{CF}_{2}\right)$

Representative procedure for the synthesis of 2 -(4-n-tridecafluoro-phenyl)-isoindole-1,3-dione (1) A $50 \mathrm{ml}$ one-neck flask equipped with a magnetic stir bar and reflux condenser was charged with phthalic anhydride $(0.441 \mathrm{~g}, 3 \mathrm{mmol}$ ), 4- $n$-(tridecafluorohexyl)aniline $(1.44 \mathrm{~g}, 3.5 \mathrm{mmol})$ and $20 \mathrm{ml}$ glacial acetic acid. This mixture was stirred for $2 \mathrm{~h}$. at room temperature followed by refluxing $(12 \mathrm{~h}$.). Ujpon cooling colorless crystals formed which were collected by filtration and recrystallized once more from ethanol. Yield: $1.44 \mathrm{~g}$ $(89 \%) ; \mathrm{t}_{r}=0.3 ;{ }^{1} \mathrm{H}-\mathrm{NMR}\left(\mathrm{CDCl}_{3}\right) \delta(\mathrm{ppm}): 7.67(\mathrm{~d}, 2 \mathrm{H}, J=8 \mathrm{~Hz}), 7.73(\mathrm{~d}, 2 \mathrm{H}, J=9 \mathrm{~Hz}), 7.81(\mathrm{t}, J=3 \mathrm{~Hz}$, $1 \mathrm{H}), 7.82(\mathrm{~s}, 1 \mathrm{H}), 7.95(\mathrm{~s}, 1 \mathrm{H}), 7.97(\mathrm{t}, J=3 \mathrm{~Hz}, 1 \mathrm{H}) ;{ }^{13} \mathrm{C}-\mathrm{NMR} \delta(\mathrm{ppm}): 123.9,126,127.6,127.7,131.3$, 
134.6, 135.1, $166.5 ;{ }^{19} \mathrm{~F}-\mathrm{NMR} \delta(\mathrm{ppm}):-81\left(\omega-\mathrm{CF}_{3}\right),-111\left(\epsilon-\mathrm{CF}_{2}\right),-122\left(\delta, \gamma-\mathrm{CF}_{2}\right),-123\left(\beta-\mathrm{CF}_{2}\right),-126$ $\left(\alpha-\mathrm{CF}_{2}\right) ; \mathrm{FT}-\mathrm{IR}(\mathrm{KBr}) 1717\left(\mathrm{C}=O_{\text {imide }}\right), 1782\left(\mathrm{C}=O_{\text {imide }}\right) \mathrm{cm}^{-1}$

Analytical data of 5-methyl-2-(4-n-tridecafluorohexyl-phenyl)-isoindole-1,3-dione (2) Yield: $1.45 \mathrm{~g}$ (87\%); $\mathrm{t}_{r}=0.18 ;{ }^{1} \mathrm{H}-\mathrm{NMR}\left(\mathrm{CDCl}_{3}\right) \delta(\mathrm{ppm}): 2.55(\mathrm{~s}, 3 \mathrm{H}), 7.59(\mathrm{~d}, 1 \mathrm{H}, J=7 \mathrm{~Hz}), 7.66(\mathrm{~d}, 2 \mathrm{H}, J=9 \mathrm{~Hz}), 7.71(\mathrm{~d}$, $2 \mathrm{H}, J=9 \mathrm{~Hz}), 7.76(\mathrm{~s}, 1 \mathrm{H}), 7.84(\mathrm{~d}, 1 \mathrm{H}, J=7 \mathrm{~Hz}) ;{ }^{13} \mathrm{C}-\mathrm{NMR} \delta(\mathrm{ppm}): 22.6,123.7,124.3,125.9,127.4,127.5$, $127.6,128.7,131.6,135.1,146,166.5,166.6 ;{ }^{19} \mathrm{~F}-\mathrm{NMR} \delta(\mathrm{ppm}):-81\left(\omega-\mathrm{CF}_{3}\right),-111\left(\epsilon-\mathrm{CF}_{2}\right),-122\left(\delta, \gamma-\mathrm{CF}_{2}\right)$, $-123\left(\beta-\mathrm{CF}_{2}\right),-127\left(\alpha-\mathrm{CF}_{2}\right)$; FT-IR $(\mathrm{KBr}) 1726\left(C=O_{\text {imide }}\right), 1781\left(C=O_{\text {imide }}\right) \mathrm{cm}^{-1}$

Analytical data of 5-methoxy-20-(4-n-tridecafluorohexyl-phenyl)-isoindole-1.3-dione (3) Yield: $1.61 \mathrm{~g}$ $(94 \%) ; \mathrm{t}_{r}=0.16 ;{ }^{1} \mathrm{H}-\mathrm{NMR}\left(\mathrm{CDCl}_{3}\right) \delta(\mathrm{ppm}): 3.95(\mathrm{~s}, 3 \mathrm{H}), 7.25(\mathrm{dd}, 1 \mathrm{H}, J=6 \mathrm{~Hz}), 7.42(\mathrm{~d}, 1 \mathrm{H}, J=3 \mathrm{~Hz}), \tau .65$ $(\mathrm{d}, 2 \mathrm{H}, J=9 \mathrm{~Hz}), 7.71(\mathrm{~d}, 2 \mathrm{H}, J=8 \mathrm{~Hz}), 7.86(\mathrm{~d}, 1 \mathrm{H}, J=8 \mathrm{~Hz}) ;{ }^{13} \mathrm{C}-\mathrm{NMR} \delta$ (ppm): 54.1, 56.2, 108.3, 120.7, $123.2,125.6,125.9,127.6,134,135.3,165.1,166.2,166.4 ;{ }^{19} \mathrm{~F}-\mathrm{NMR} \delta(\mathrm{ppm}):-81\left(\omega-\mathrm{CF}_{3}\right),-111\left(\epsilon-\mathrm{CF}_{2}\right)$, $-122\left(\delta, \gamma-\mathrm{CF}_{2}\right),-123\left(\beta-\mathrm{CF}_{2}\right),-127\left(\alpha-\mathrm{CF}_{2}\right)$; FT-IR $(\mathrm{KBr}) 1718\left(C=O_{\text {imide }}\right), 1782\left(\mathrm{C}=O_{\text {imide }} \mathrm{cm}^{-1}\right.$

Analytical data of 5-nitro-2-(4-n-tridecafluorohexyl-phenyl)-isoindole-1,3-dione (4) Yield: $1.32 \mathrm{~g}(75 \%)$; $\mathrm{t}_{r}=0.25 ;{ }^{1} \mathrm{H}-\mathrm{NMR}\left(\mathrm{CDCl}_{3}\right) \delta(\mathrm{ppm}): 7.67(\mathrm{~d}, 2 \mathrm{H}, J=8 \mathrm{~Hz}), 7.76(\mathrm{~d}, 2 \mathrm{H}, J=9 \mathrm{~Hz}), 8.18(\mathrm{~d}, 1 \mathrm{H}, J=8 \mathrm{~Hz})$, $8.69(\mathrm{dd}, 1 \mathrm{H}, J=2 \mathrm{~Hz}), 8.78(\mathrm{~d}, 1 \mathrm{H}, J=2 \mathrm{~Hz}) ;{ }^{13} \mathrm{C}-\mathrm{NMR} \delta(\mathrm{ppm}): 118.0,123.9,124.6,126.6,127.4,128.5$, 131.4, 133, 134.3, 150.T, 162.9, 163.2; ${ }^{19} \mathrm{~F}-\mathrm{NMR} \delta(\mathrm{ppm}):-81\left(\omega-\mathrm{CF}_{3}\right),-111\left(\epsilon-\mathrm{CF}_{2}\right),-122\left(\delta, \gamma-\mathrm{CF}_{2}\right),-123$ $\left(\beta-\mathrm{CF}_{2}\right),-126\left(\alpha-\mathrm{CF}_{2}\right)$; FT-IR $(\mathrm{KBr}) 1717\left(\mathrm{C}=O_{\text {imide }}\right), 1780\left(\mathrm{C}=O_{\text {imide }}\right) \mathrm{cm}^{-1}$

Analytical data of 4-fluoro-2-(4-n-tridecafluorohexyl-phenyl)-isoindole-1,3-dione (5) Yield: $1.54 \mathrm{~g}(92 \%)$; $\mathrm{t}_{r}=0.11 ;{ }^{1} \mathrm{H}-\mathrm{NMR}\left(\mathrm{CDCl}_{3}\right) \delta(\mathrm{ppm}): 7.46(\mathrm{tt}, 1 \mathrm{H}, J=2 \mathrm{~Hz}), 7.64(\mathrm{~d}, 2 \mathrm{H}, J=9 \mathrm{~Hz}), 7.72(\mathrm{~d}, 2 \mathrm{H}, J=8 \mathrm{~Hz})$, $7.8(\mathrm{~m}, 2 \mathrm{H}) ;{ }^{13} \mathrm{C}-\mathrm{NMR} \delta(\mathrm{ppm}): 120,120.1,122.7,123,126,127.7,133.4,134.6,13 \bar{\tau}, 137.1,156,159.6$, $163.1,165.3 ;{ }^{19} \mathrm{~F}-\mathrm{NMR} \delta(\mathrm{ppm}):-81\left(\omega-\mathrm{CF}_{3}\right),-111\left(\epsilon-\mathrm{CF}_{2}\right),-112(\mathrm{~F}-\mathrm{Ar}),-122\left(\delta, \gamma-\mathrm{CF}_{2}\right),-123\left(\beta-\mathrm{CF}_{2}\right)$, $-127\left(\alpha-\mathrm{CF}_{2}\right)$; FT-IR (KBr) $1724\left(C=O_{\text {imide }}\right), 1784\left(\mathrm{C}=O_{\text {imide }}\right) \mathrm{cm}^{-1}$

Analytical data of 5-fluoro-2-(4-n-tridecafluorohexyl-phenyl)-isoindole-1,3-dione (6) Yield: $1.49 \mathrm{~g}(89 \%)$; $\mathrm{t}_{r}=0.34 ;{ }^{1} \mathrm{H}-\mathrm{NMR}\left(\mathrm{CDCl}_{3}\right) \delta(\mathrm{ppm}): 7.48(\mathrm{tt}, 1 \mathrm{H}, J=2 \mathrm{~Hz}), 7.64(\mathrm{~m}, 1 \mathrm{H}), 7.65(\mathrm{~d}, 2 \mathrm{H}, J=8 \mathrm{~Hz}), 7.73(\mathrm{~d}$, $2 \mathrm{H}, J=8 \mathrm{~Hz}), 7.98(\mathrm{q}, 1 \mathrm{H}, J=4 \mathrm{~Hz}) ;{ }^{13} \mathrm{C}-\mathrm{NMR} \delta(\mathrm{ppm}): 111.4,111.8,121.6,121.9,125.9,126.3,126.4,127 . \bar{t}$, $134.1,134.9,164.9,165.2,165.4,168.3 ;{ }^{19} \mathrm{~F}-\mathrm{NMR} \delta(\mathrm{ppm}):-81\left(\omega-\mathrm{CF}_{3}\right),-101(\mathrm{~F}-\mathrm{Ar}),-111\left(\epsilon-\mathrm{CF}_{2}\right),-122(\delta$, $\left.\gamma-\mathrm{CF}_{2}\right),-123\left(\beta-\mathrm{CF}_{2}\right),-126\left(\alpha-\mathrm{CF}_{2}\right)$; FT-IR $(\mathrm{KBr}) 1717\left(C=O_{\text {imide }}\right), 1784\left(C=O_{\text {imide }}\right) \mathrm{cm}^{-1}$

Analytical data of 4-chloro- - -(4-n-tridecafluorohexyl-phenyl)-isoindole-1,3-dione (7) Yield: $1.15 \mathrm{~g}(66 \%)$; $\mathrm{t}_{r}=0.25 ;{ }^{1} \mathrm{H}-\mathrm{NMR}\left(\mathrm{CDCl}_{3}\right) \delta(\mathrm{ppm}): 7.69(\mathrm{~m}, 6 \mathrm{H}), 7.88(\mathrm{t}, 1 \mathrm{H}, J=4 \mathrm{~Hz}) ;{ }^{13} \mathrm{C}-\mathrm{NMR} \delta(\mathrm{ppm}): 122.5,126.2$, $127.2,127.7,128.4,132.3,133.6,134.9,135.6,136.5,164.3,165.3 ;{ }^{19} \mathrm{~F}-\mathrm{NMR} \delta(\mathrm{ppm}):-81\left(\omega-\mathrm{CF}_{3}\right),-111$ $\left(\epsilon-\mathrm{CF}_{2}\right),-122\left(\delta, \gamma-\mathrm{CF}_{2}\right),-123\left(\beta-\mathrm{CF}_{2}\right),-127\left(\alpha-\mathrm{CF}_{2}\right)$; FT-IR $(\mathrm{KBr}) 1721\left(C=O_{\text {imide }}\right), 1776\left(C=O_{\text {imide }}\right)$ $\mathrm{cm}^{-1}$

Analytical data of 5-chloro-2-(4-n-tridecafluorohexyl-phenyl)-isoindole-1,3-dione (8) Yield: $1.66 \mathrm{~g}(96 \%)$; $\mathrm{t}_{r}=0.34 ;{ }^{1} \mathrm{H}-\mathrm{NMR}\left(\mathrm{CDCl}_{3}\right) \delta(\mathrm{ppm}): 7.65(\mathrm{~d}, 2 \mathrm{H}, J=9 \mathrm{~Hz}), 7.73(\mathrm{~d}, 2 \mathrm{H}, J=9 \mathrm{~Hz}), 7.77(\mathrm{dd}, 1 \mathrm{H}, J=8 \mathrm{~Hz})$, $7.90(\mathrm{~d}, 1 \mathrm{H}, J=9 \mathrm{~Hz}), 7.94(\mathrm{~d}, 1 \mathrm{H}, J=2 \mathrm{~Hz}) ;{ }^{13} \mathrm{C}-\mathrm{NMR} \delta(\mathrm{ppm}): 124.2,125.0,125.9,127.7,128.1,129.3$, $132.9,134.6,134.8,141.4,165.2,165.5 ;{ }^{19} \mathrm{~F}-\mathrm{NMR} \delta(\mathrm{ppm}):-81\left(\omega-\mathrm{CF}_{3}\right),-111\left(\epsilon-\mathrm{CF}_{2}\right),-122\left(\delta, \gamma-\mathrm{CF}_{2}\right),-123$ $\left(\beta-\mathrm{CF}_{2}\right),-127\left(\alpha-\mathrm{CF}_{2}\right)$; FT-IR (KBr) $1717\left(C=O_{\text {imide }}\right), 1773\left(C=O_{\text {imide }}\right) \mathrm{cm}^{-1}$

Analytical data of 4-bromo-2-(4-n-tridecafluorohexyl-phenyl)-isoindole-1,3-dione (9) Yield: $0.54 \mathrm{~g}(79 \%)$; $\mathrm{t}_{r}=0.14 ;{ }^{1} \mathrm{H}-\mathrm{NMR}\left(\mathrm{CDCl}_{3}\right) \delta(\mathrm{ppm}): 7.70(\mathrm{~m}, 5 \mathrm{H}), 7.93(2,2 \mathrm{H}, J=7 \mathrm{~Hz}) ;{ }^{13} \mathrm{C}-\mathrm{NMR} \delta(\mathrm{ppm}): 119.4,123.1$, $126.2,127.8,128.4,129,133.8,135,135.5,139.7,164.7,165.1 ;{ }^{19} \mathrm{~F}-\mathrm{NMR} \delta(\mathrm{ppm}):-81\left(\omega-\mathrm{CF}_{3}\right),-111\left(\epsilon-\mathrm{CF}_{2}\right)$, $-122\left(\delta, \gamma-\mathrm{CF}_{2}\right),-123\left(\beta-\mathrm{CF}_{2}\right),-127\left(\alpha-\mathrm{CF}_{2}\right) ; \mathrm{FT}-\mathrm{IR}(\mathrm{KBr}) 1716\left(C=O_{\text {imide }}\right) \mathrm{cm}^{-1}$

Analytical data of 5-bromo-⿱⿹勹⿰丿丿心-(4-n-tridecafluorohexyl-phenyl)-isoindole-1,3-dione (10) Yield: $1.71 \mathrm{~g}$ $(92 \%) ; \mathrm{t}_{r}=0.41 ;{ }^{1} \mathrm{H}-\mathrm{NMR}\left(\mathrm{CDCl}_{3}\right) \delta(\mathrm{ppm}): 7.64(\mathrm{~d}, 2 \mathrm{H}, J=9 \mathrm{~Hz}), 7.72(\mathrm{~d}, 2 \mathrm{H}, J=8 \mathrm{~Hz}), 7.82(\mathrm{~d}, 1 \mathrm{H}$, 
$J=7 \mathrm{~Hz}), 7.93(\mathrm{dd}, 1 \mathrm{H}, J=9 \mathrm{~Hz}), 8.09(\mathrm{~d}, 1 \mathrm{H}, J=1 \mathrm{~Hz}) ;{ }^{13} \mathrm{C}-\mathrm{NMR} \delta(\mathrm{ppm}): 125.4,126.1,127.4,127.9,128$, $129.8,130,133.1,135,137,165.4,165.9 ;{ }^{19} \mathrm{~F}-\mathrm{NMR} \delta(\mathrm{ppm}):-81\left(\omega-\mathrm{CF}_{3}\right),-111\left(\epsilon-\mathrm{CF}_{2}\right),-122\left(\delta, \gamma-\mathrm{CF}_{2}\right)$, $-123\left(\beta-\mathrm{CF}_{2}\right),-127\left(\alpha-\mathrm{CF}_{2}\right)$; FT-IR $(\mathrm{KBr}) 1717\left(C=O_{\text {imide }}\right), 1717\left(C=O_{\text {imide }}\right), 1769\left(C=O_{\text {imide }}\right) \mathrm{cm}^{-1}$

Analytical data of 5,6-dichloro-2-(4-n-tridecafluorohexyl-phenyl)-isoindole-1,3-dione (11) Yield: $1.75 \mathrm{~g}$ $(96 \%) ; \mathfrak{t}_{r}=0.48 ;{ }^{1} \mathrm{H}-\mathrm{NMR}\left(\mathrm{CDCl}_{3}\right) \delta(\mathrm{ppm}): 7.63(\mathrm{~d}, 2 \mathrm{H}, J=9 \mathrm{~Hz}), 7.72(\mathrm{~d}, 2 \mathrm{H}, J=9 \mathrm{~Hz}), 8.04(\mathrm{~s}, 2 \mathrm{H}) ;$ ${ }^{13} \mathrm{C}-\mathrm{NMR} \delta(\mathrm{ppm}): 125.9,127.8,130.4,134.7,139.8,164.6,186.4 ;{ }^{19} \mathrm{~F}-\mathrm{NMR} \delta(\mathrm{ppm}):-81\left(\omega-\mathrm{CF}_{3}\right),-111$ $\left(\epsilon-\mathrm{CF}_{2}\right),-122\left(\delta, \gamma-\mathrm{CF}_{2}\right),-123\left(\beta-\mathrm{CF}_{2}\right),-127\left(\alpha-\mathrm{CF}_{2}\right)$; FT-IR $(\mathrm{KBr}) 1723\left(C=O_{\text {imide }}\right), 178.5\left(C=O_{\text {imide }}\right)$ $\mathrm{cm}^{-1}$

Analytical data of 4,7-dichloro-2-(4-n-tridecafluorohexyl-phenyl)-isoindole-1,3-dione (12) Yield: $1.67 \mathrm{~g}$ $(91 \%) ; \mathrm{t}_{r}=0.59 ;{ }^{1} \mathrm{H}-\mathrm{NMR}\left(\mathrm{CDCl}_{3}\right) \delta(\mathrm{ppm}): 7.6-7.9(\mathrm{~m}, 6 \mathrm{H}) ;{ }^{13} \mathrm{C}-\mathrm{NMR} \delta(\mathrm{ppm}): 126.1,127.6,128.4$, $130.6,134.3,137,162.7 ;{ }^{19} \mathrm{~F}-\mathrm{NMR} \delta(\mathrm{ppm}):-81\left(\omega-\mathrm{CF}_{3}\right),-111\left(\epsilon-\mathrm{CF}_{2}\right),-122\left(\delta, \gamma-\mathrm{CF}_{2}\right),-123\left(\beta-\mathrm{CF}_{2}\right),-127$ $\left(\alpha-\mathrm{CF}_{2}\right)$; FT-IR $(\mathrm{KBr}) 1716\left(C=O_{\text {imide }}\right) \mathrm{cm}^{-1}$

Analytical data of 4,5,6,7-tetrachloro-2-(4-n-tridecafluorohexyl-phenyl)-isoindole-1,3-dione (13) Yield: $1.93 \mathrm{~g}(95 \%) ; \mathrm{t}_{r}=0.37 ;{ }^{1} \mathrm{H}-\mathrm{NMR}\left(\mathrm{CDCl}_{3}\right) \delta(\mathrm{ppm}): 7.62(\mathrm{~d}, 2 \mathrm{H}, J=9 \mathrm{~Hz}), 7.74(\mathrm{~d}, 2 \mathrm{H}, J=8 \mathrm{~Hz}) ;{ }^{13} \mathrm{C}-\mathrm{NMR}$ $\delta(\mathrm{ppm}): 126,126.7,127.7,130.2,134,140.8,161.8 ;{ }^{19} \mathrm{~F}-\mathrm{NMR} \delta(\mathrm{ppm}):-81\left(\omega-\mathrm{CF}_{3}\right),-111\left(\epsilon-\mathrm{CF}_{2}\right),-122(\delta$, $\left.\gamma-\mathrm{CF}_{2}\right),-123\left(\beta-\mathrm{CF}_{2}\right),-126\left(\alpha-\mathrm{CF}_{2}\right) ;$ FT-IR $(\mathrm{KBr}) 1717\left(C=O_{\text {imide }}\right) \mathrm{cm}^{-1}$

Acknowledgements. Kenny Jow gratefully acknowledges the Langley Aerospace Research Summer Scholar (LARSS) program sponsored by Hampton Universtity. We thank C. Topping for performing DSC measurements, and Jirakorn Thisayukta at the University of North Carolina for his help with the X-ray diffraction experiments.

\section{REFERENCES}

[1] S. Sasaki and S. Nishi, Synthesis of fluorinated polyimides. in Polyimides, edited by M.K. Ghosh and K.L. Mittal, Marcel Dekker, 1996.

[2] P. Eiselt, S. Denzinger and H. Schmidt, Liq. Cryst., 18 (1995), pp. 257.

[3] E. Bialecka-Florjanczyk and A. Orzeszko, J. Mater. Chem., 10 (2000), pp. 1527.

[4] P. Berdagué, P. Judeinstein, J.-P. Bayle, C.S. Nagaraja, N. Sinha and K.V. Ramanathan, Liq. Cryst., 28 (2001), pp. 197.

[5] C.W. Bunn and E.R. Houwens, Nature Lond., 174 (1954): pp. 549.

[6] H.T. Nguyen, G. Sigaud, M.F. Achard, F. Hardouin, R.J. Twieg and K. Betterton, Liq. Cryst., 10 (1991), pp. 389.

[7] T.A. Lobko, B.I. Ostrovskit, A.I. Pavluchenko and S.N. Sulianov, Liq. Cryst., 15 (1993), pp. 361.

[8] R. Ruhmann, T. Thiele, D. Wolff, D. Prescher and J. Springer, Liq. Cryst., 21 (1996), pp. 307 .

[9] M.E. Neubert, Chemical structure-property relationships. in Liquid Crystals, edited by S. Kumar, Cambridge University Press, 2001.

[10] C. Soucy, D. Favreau and M.M. Kayser, J. Org. Chem, 52, No. 1 (1987), pp. 129.

[11] N. Yoshino, M. Kitamura, T. Seto, Y. Shibata, M. Abe and O. Keizo, Bul. Chem. Soc. Jpn., 65 (1992), pp. 2141. 

Public reporting burden for this collection of information is estimated to average 1 hour per response, including the time for reviewing instructions, searching existing data sources, gathering and maintaining the data needed, and completing and reviewing the collection of information. Send comments regarding this burden estimate or any other aspect of this Davis Highway, Suite 1204, Arlington, VA 22202-4302, and to the Office of Management and Budget, Paperwork Reduction Project (0704-0188), Washington, DC 20503.

\begin{tabular}{|l|l|l|}
\hline 1. AGENCY USE ONLY(Leave blank) & $\begin{array}{l}\text { 2. REPORT DATE } \\
\text { December } 2001\end{array}$ & $\begin{array}{l}\text { 3. REPORT TYPE AND DATES COVERED } \\
\text { Contractor Report }\end{array}$ \\
\hline
\end{tabular}

4. TITLE AND SUBTITLE

Synthesis and

Liquid crystals
characterization

5. FUNDING NUMBERS

AUTHOR(S)

Kenny G. Jow and Theo J. Dingemans

C NAS1-97046

WU 505-90-52-01

7. PERFORMING ORGANIZATION NAME(S) AND ADDRESS(ES)

ICASE

8. PERFORMING ORGANIZATION

REPORT NUMBER

Mail Stop $132 \mathrm{C}$

NASA Langley Research Center

ICASE Report No. 2001-41

Hampton, VA 23681-2199

9. SPONSORING/MONITORING AGENCY NAME(S) AND ADDRESS(ES)

National Aeronautics and Space Administration

Langley Research Center

Hampton, VA 23681-2199

10. SPONSORING/MONITORING AGENCY REPORT NUMBER

NASA/CR-2001-211270

ICASE Report No. 2001-41

11. SUPPLEMENTARY NOTES

Langley Technical Monitor: Dennis M. Bushnell

Final Report

To appear in Liquid Crystals.

\begin{tabular}{l|l}
\hline 12a. DISTRIBUTION/AVAILABILITY STATEMENT & 12b. DISTRIBUTION CODE \\
Unclassified-Unlimited & \\
Subject Category 34 & \\
Distribution: Nonstandard & \\
Availability: NASA-CASI (301) $621-0390$ &
\end{tabular}

13. ABSTRACT (Maximum 200 words)

2-Phenyl-isoindole was investigated as the rigid core unit in a series of asymmetric mesogenic molecules. When the 2-phenyl-isoindole core was terminated with a hexyl tail, no mesophase formation could be observed. When 4-n(tridecafluorohexyl) was used, however, we observed both monotropic and enantiotropic phase behavior. We found that most functionalities at the anhydride 5-position results in the formation of smectic A (SmA) phases in the temperature range of $70-180^{\circ} \mathrm{C}$. Functionalities at the anhydride 4-position suppress mesophase formation. Large substituents $\left(-\mathrm{Br},-\mathrm{NO}_{2}\right)$ and symmetric substitution patterns (5,6-dichloro, 4,7-dichloro and 4,5,6,7-tetrachloro) on the anhydride moiety increase the melting point and destabilize the mesophase. Temperature dependent $\mathrm{X}$-ray diffraction experiments suggest an interdigitated SmA packing for this family of compounds.

\section{SUBJECT TERMS and filters

17. SECURITY CLASSIFICATION
OF REPORT
Unclassified

liquid crystals, smectic A, 2-phenyl-isoindole, fluorinated imides, self-adaptive optics

NSN 7540-01-280-5500
15. NUMBER OF PAGES 18

16. PRICE CODE

$\mathrm{A} 03$

\begin{tabular}{l|l|} 
18. SECURITY CLASSIFICATION & 19. SECURITY CLASSIFICATION \\
OF THIS PAGE & OF ABSTRACT \\
Unclassified &
\end{tabular}

20. LIMITATION OF ABSTRACT

Standard Form 298(Rev. 2-89)

Prescribed by ANSI Std. Z39-18 298-102 